\title{
KRITIK TERHADAP PEMAHAMAN YANG MENYATAKAN BAHWA KEPEMIMPINAN ISLAM HARUS BERASAL DARI BANI QURAISY
}

\author{
Canra Krisna Jaya \\ Dosen Fakultas Ushuluddin STAI Nurul Iman Parung, Bogor \\ E-mail: canrakrisnajaya@gmail.com
}

\begin{abstract}
Leadership is very important in a group especially in an area or country. With the existence of a leader, the rules of life will be carried out well with the teachings of religion and the beginning for the realization of the people, so that the life of the community becomes safe and prosperous. Although basically all humans are God's caliphs who have equality in this Caliphate. The conclusions of the writer in the topic that someone has the right to be a leader if he has expertise in his field. The approach taken in this study using a sociological approach to the Hadith, so that it can be seen that the Quraysh descent is not intended as an absolute condition for the position of head of state established by the Prophet, so that all people are eternally binding. The Hadith only shows that the leadership of the descendants of Qurasiy is only a condition of virtue, because it is well known for its solidarity. In the explanation of the Hadith, it is only local-temporal. Because contrary to the principle of the Qur'an which states that the most important before God is the most pious person, not from any circles, groups or descendants (there is no specialization for the Quraysh..
\end{abstract}

Keywords:

Banu Quraysh, Islam, Leadership

\begin{abstract}
Abstrak
Kepemimpinan merupakan suatu yang sangat penting dalam sebuah kelompok apalagi dalam suatu daerah maupun negeri. Dengan adanya seorang peminpin maka aturan kehidupan akan terlaksana dengan baik ajaran-ajaran agama dan awal bagi terwujudnya umat, sehingga kehidupan masyarakat menjadi aman dan sejahtera. Meskipun pada dasarnya semua manusia merupakan khalifah Tuhan yang memiliki kesetaraan dalam kekhalifahan ini. Adapun yang menjadi kesimpulan penulis dalam topik bahwa seseorang berhak menjadi seorang peminpin apabila ia mempunyai keahlian dalam bidangnya. Adapun pendekatan yang dilakukan dalam penelitian ini dengan menggunakan pendekatan sosiologis terhadap Hadis, sehingga dapat diketahui bahwa keturunan Quraisy tidak dimaksudkan sebagai syarat mutlak bagi jabatan kepala negara yang ditetapkan oleh Nabi, sehingga mengikat seluruh umat secara abadi. Hadis tersebut hanya menunjukkan bahwa kepemimpinan dari keturunan Qurasiy hanya sebagai syarat keutamaan, karena memang terkenal dengan solidaritasnya. Dalam penjelasan Hadis tersebut hanya bersifat lokaltemporal. Karena bertolak belakang dengan prinsip al-Qur'an yang menyatakan bahwa yang paling utama dihadapan Allah adalah orang yang paling bertakwa, bukan dari kalangan, golongan atau keturunan manapun (tidak ada pengkhusususan untuk kaum Quraisy.
\end{abstract}

Kata Kunci:

Bani Quraisy, Agama Islam, Kepemimpinan

\section{A. PENDAHULUAN}

Hadis atau sunnah Nabi Saw dalam pemahaman dan pandangan umat Islam adalah sebagai salah satu sumber ajaran Islam. Secara hierarki hadis menempati posisi kedua setelah alQur'an. Kemudian secara fungsional menempati posisi sebagai bayan atau penjelas terhadap alQur'an. Posisi ini mengandung makna yang signifikan dan strategis. Oleh karena itu terasa penting untuk menggali dasar maupun prinsip ajaran Islam yang terkandung dalam hadis-hadis tersebut. Salah satu prinsip ajaran yang terkandung di dalamnya adalah yang berkenaan dengan kepemimpinan.

Di dalam Islam terdapat pandangan bahwa seorang pemimpin merupakan hal yang penting dalam sebuah masyarakat. Hal ini dapat diamati dari posisi Rasulullah Saw sebagai seorang pengayom ataupun pemimpin kaum muslimin. Diamati dari perjalanan sejarah, maka ada tiga kedudukan yang diperankan oleh Rasul Saw. Adapun posisi atau kedudukan Nabi yang 
pertama ialah kenabian atau kerasulan, yakni kedudukan sebagai pembawa dan penyampai hukum-hukum Allah yang diwahyukan kepadaNya. Dan Nabi mempunyai tugas untuk menyampaikan hukum-hukum itu kepada umat manusia. Posisi kedua adalah sebagai penentu dan pemutus hukum. Berdasarkan hal tersebut, Nabi bertugas untuk menegakkan kebenaran bila terjadi pertentangan dan perselisihan di antara manusia dengan berstandar pada satu hukum. Dalam hal ini posisi Nabi sebagai seorang pemutus dan penetap solusi untuk suatu masalah. Posisiketiga adalah sebagai pemimpindan pemegang kendali pemerintahan. Nabi adalah pengayom sekaligus pengatur yang menangani berbagai urusan masyarakat.

Kepemimpinan merupakan hal yang prinsip bagi terlaksananya dengan baik ajaranajaran agama dan awal bagi terwujudnya umat, sehingga kehidupan masyarakat menjadi aman dan sejahtera. Dari keterangan tersebut, maka muncul pertanyaan siapakah yang dianggap mampu menggantikan posisi Rasul sebagai pemimpin dalam sebuah pemerintahan?. Tentu tidak sembarang orang yang dapat menduduki jabatan tersebut, terlebih tugas seorang pemimpin yang begitu berat. Tentunya hanya dapat disandang oleh seseorang yang berkompeten untuk menjadi pemimpin. Meskipun pada dasarnya semua manusia merupakan khalifah Tuhan yang memiliki kesetaraan dalam kekhalifahan ini.

Dalam ajaran Islam yang asasi tidak dikenal adanya pembagian kelompok yang didasarkan pada perbedaan kelahiran dan kedudukan sosial. Semua orang mempunyai kedudukan dan status yang sama. Kriteria yang diunggulkan untuk menjadi seorang pemimpin adalah kemampuan pribadi dan karakternya. Dan yang menjadi topik pembahasan dalam makalah ini adalah mengenai pernyataan yang dikutip dari rasul tentang pemimpin itu berasal dari Quraisy. Bagaimanakah pemahaman terhadap teks hadis tersebut ditinjau dari kajian normatif dan realitas sosial, apalagi kalau diamati dengan perkembangan politik dan pluralitas saat sekarang ini.

\section{B. HASIL DAN PEMBAHASAN \\ 1. Hadis-Hadis yang berkenaan dengan Pemimpin dari Bani Quraisy}

Hadis-hadis yang beredar di tengah-tengah masyarakat dan dijadikan sebagai pegangan oleh umat Islam dalam kaitannya dengan hadis sebagai sumber ajaran Islam adalah merupakan hadis-hadis yang tersusun dalam berbagai kitab yang penulisan atau penyusunannya dilakukan setelah berabad lamanya dari rasulullah wafat. Dengan rentang waktu yang begitu lama tersebut, diperkirakan terjadi berbagai hal yang bisa menjadikan riwayat hadis menyalahi apa yang sebenarnya berasal dari Nabi Saw. Oleh karena itu, untuk mengetahui apakah berbagai periwayatan itu bisa dijadikan hujjah ataukah tidak, perlu terlebih dahulu dilakukan sebuah penelitian. Hal ini dilakukan tidak terbatas pada materi hadis tetapi juga yang berkaitan dengan sanadnya. ${ }^{1}$

Adapun yang perlu dicermati dalam meneliti keshahihan sanad hadis adalah terdapat unsurunsur keshahihan sanad hadis yang bersifat umum dan khusus atau dalam istilah Syuhudi Ismail ada kaedah mayor dan ada kaedah minor. ${ }^{2}$ Unsur-unsur keshahihan sanad hadis adalah: Memiliki sanad yang bersambung. Seluruh periwayat dalam sanad bersifat adil. Seluruh periwayat dalam sanad bersifat dhabit. Sanad hadis terhindar dari syudzuz. Sanad hadis terhindar dari 'illat. ${ }^{3}$

1 M. Syuhudi Ismail, Metodologi Penelitian Hadis Nabi, Cet. II (Jakarta: P.T. Bulan Bintang, 2007), h. 4

2 M. Syuhudi Ismail, Kaedah Kesahihan Sanad Hadis: Telaah Kritis dan Tinjauan dengan Pendekatan Ilmu Sejarah, Cet. II (Jakarta: P.T. Bulan Bintang, 1995), h. 119

${ }^{3}$ M. Syuhudi Ismail, Kaedah Kesahihan Sanad..., h. 126. Salah satu kutipan Syuhudi terhadap kaedah kesahihan sanad hadis adalah defenisi yang diuraikan oleh Ibn Al Shalah yaitu:

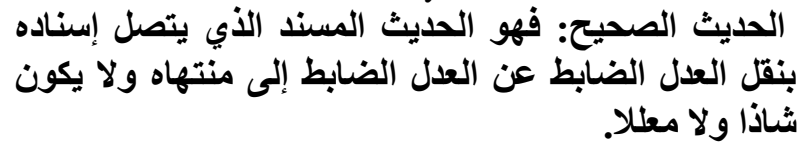

lihat, Abu 'Amr al Sahrazuri, Muqaddimat Ibn Al Shalah fi 'Ulum al Hadis Cet. II (Beirut: Dar al Kutub Al 'Ilmiyah, 2006), h. 18. Dan keterangan yang diuraikan oleh Al Nawawi yaitu: 
Berdasarkan pengamatan Syuhudi bahwa kaedah mayor keshahihan sanad hadis bisa difokuskan kepada tiga point saja yaitu, sanad bersambung, periwayat bersifat adil dan memiliki sifat dhabit atau tamm al dhabt. Sementara kaedah minornya untuk masingmasing poin di atas adalah:

1. Sanad bersambung kaedah minornya muttashil, marfu'dan mahfudzh dan bukan mu'all (tidak merupakan hadis yang ber'illat)

2. Periwayat hadis bersifat adil, kaedah minornya adalah beragama Islam, mukallaf, melaksanakan ketentuan agama dan memelihara muru'ah

3. Periwayat bersifat dhabit atau tamm al dhabt kaedah minornya adalah periwayat memahami dan hafal dengan baik riwayat yang diterimanya, mampu menyampaikan riwayat yang dihafalnya itu dengan baik, terhindar dari syadzdan terbebas dari 'illat ${ }^{4}$

Sementara itu, untuk meneliti kualitas keshahihan suatu matan hadis tidak bisa terlepas dari dua acuan utama. Hal tersebut adalah harus terhindar dari syudzuz (kejanggalan) dan terhindar dari 'illah (cacat). ${ }^{5}$ Adapun tolok ukur penelitian suatu matan (Ma'ayir naqd al matn) memiliki keragaman di antara para ulama. Salah satu ulama yang memberikan uraian tentang kriteria terhadap penerimaan matan suatu hadis adalah Al Khatib al Bagdadi (W. 463 H/1072 M). Beliau berpendapat bahwa suatu hadis bisa dinyatakan diterima matannya apabila memenuhi persyaratan sebagai berikut:

ما اتصل سنده بالعدول الضابطين من غير شذوذ ولا علة lihat, Jalaluddin Al Suyuti, Tadrib Al Rawi fi Syarh Taqrib Al Nawawi (Kairo: Dar Al Hadis, 2004), h. 45, juga bisa dilihat pada, Syaikh Muhammad Al Ghazali, Hadis Nabi saw : Antara Pemahaman Tekstual dan Kontekstual, alih bahasa oleh Muhammad al Baqir (Bandung: Penerbit Mizan, 1998), h. 21.

4 Syuhudi mengelompokkan Syadz atau Syudzuz sebagai kaedah minor dari dhabit sementara 'illat bagian dari kaedah minor dhabit dan sanad, lihat,M. Syuhudi Ismail, Kaedah Kesahihan Sanad..., h. 150

${ }^{5} \mathrm{M}$. Syuhudi Ismail, Metodologi Penelitian Hadis..., h. 116
1. Tidak berlawanan (kontradiktif) dengan hukum logika

2. Tidak bertentangan dengan hukum al Qur'an yang muhkam

3. Tidak bertentangan dengan hadis yang sudah maklum atau mutawatir

4. Tidak bertentangan dengan amalan yang telah menjadi kesepakatan ulama salaf

5. Tidak kontradiktif dengan dalil yang telah pasti

6. Tidak bertentang dengan hadis ahad yang lain yang kualitasnya lebih kuat. ${ }^{6}$

Adapun ulama lainnya seperti Shalah al din al adlabi. Beliau menyatakan bahwa di antara tolak ukurnya yang pertama adalah: tidak ada kontradiksi antara matan hadis dengan al Qur'an. Kedua: hadis tersebut tidak berlawanan dengan hadis yang lebih kuat, ketiga: sesuai dan selaras dengan akal sehat dan keempat, bahasa yang disampaikan adalah bahasa kenabian. $^{7}$

Berdasar kepada kerangka berpikir di atas pembahasan sekaligus pencarian hadis tentang kepemimpinan dari Bani Quraisy bisa ditelusuri lebih awal dengan memakai alat bantu kamus hadis al Mu'jam al-Mufahras li Al fadz al Hadis al Nabawi, karya A.J. Wensinck yang telah dialih bahasakan ke dalam bahasa Arab oleh Muhammad Fu'ad Abd al Baqi. Hadis tentang kepemimpinan dari bani Quraisy ini menjadi wacana dialog argumentatif dan perdebatan di antara ulama dan khususnya tokoh pemikir politik Islam.

Adapun cara penelusuran hadis tentang kepemimpinan dari bani Quraisy dari kitab Mu'jam tersebut adalah dengan memilih salah satu mufradatnya atau kosa kata yang terkandung dalam hadis tersebut. Salah satu kosa katanya diambil dari bentuk isim misalnya seperti kataimam atau

\footnotetext{
${ }^{6}$ Shalahuddin bin Ahmad al Adlabi, Manhaj al Naqd al Matan (Beirut: Dar Jadidah, 1983), h. 236

${ }^{7}$ Shalahuddin bin Ahmad al Adlabi, Manhaj al Naqd....., h. 237-238. Pembahasan lebih lanjut tentang kriteria kritik matan bisa juga diperdalam dengan merujuk kepada, Musfar Azmullah al Damini, Maqayis Naqd Mutun.... , h. 55-56.
} 
aimmah, ${ }^{8}$ diperoleh informasi penggalan hadis berupa الأئمة من قريش. Penggalan hadis ini bisa dilihat dalam kitab Musnad Ahmad bin Hanbal yang memuat delapan riwayat yaitu terdapat pada juz II ada berkisar 3 riwayat, juz III sekitar dua riwayat dan Juz IV ada 3 riwayat. Adapun di antara hadis tersebut adalah :

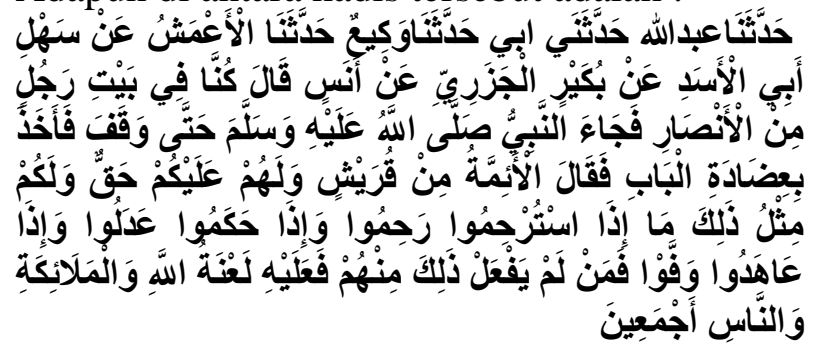

Artinya:

Bercerita 'Abd Allāh, menceritakan kepadaku, ayahku, bercerita Wakì' bercerita al-A'masy dari Suhail bin Abī al-Asad dari Bukair al-Jazarī dari Anas ia berkata: Kami sedang berada di rumah salah seorang Anshar, kemudian Nabi saw. datang dan berdiri di depan pintu seraya bersabda: "Kepemimpinan itu di tangan Quraisy". Apabila mereka mempunyai hak atas kalian dan kalian pun mempunyai hak atas mereka. Apabila mereka diminta untuk berbelas kasih, mereka akan memberikan belah kasih, apabila mereka berjanji, mereka menepati, dan apabila mereka menghakimi, mereka berlaku adil. Barang siapa diantara mereka yang tidak melaksanakan hal tersebut, maka laknat Allah, malaikat, dan seluruh manusia atas mereka. $^{9}$

Hadis berikutnya adalah:

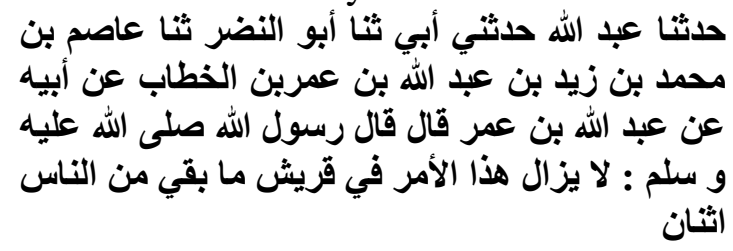

Artinya:

Menceritakan kepada kami 'Abd Allāh bahwasanya ayahnya bercerita: menceritakan kepada kami Abū al-Nadar, menceritakan

${ }^{8}$ A.J. Wensinck, al-Mu'jam al-Mufahras li Alfāz al-Hadīs an-Nabawī, Juz I, (Leiden: E-J.Brill, 1942), h. 92

${ }^{9}$ Ahmad bin Muhammad bin Hanbal, Musnad Imam Ahmad bin Hanbal, Juz II (Beirut: al-Maktabah al-Islamī, 1398), h. 183. kepada kami 'Āshim bin Muhammad bin Zayd bin 'Abd Allāh bin 'Umar bin alKhattāb dari ayahnya dari 'Abd Allāh bin 'Umar ia berkata, Nabi saw. bersabda: "Kepemimpinan ini selalu berada pada Quraisy, sekalipun sisa manusia hanya tinggal berdua. ${ }^{10}$

Adapun hadis selanjutnya adalah: Artinya:

Bercerita 'Abd Allāh, menceritakan kepadaku, ayahku, bercerita 'Affān, bercerita Sukain bin 'Abd al-Azīz, bercerita Sayyār bin Salāmah 'Abu al- Minhāl ia berkata: "Aku pergi bersama ayahku kepada 'Abu Barzahpada saat itu di telingaku ada dua antinganting, pada saat itu aku masih anak- anakRasulullah saw. bersabda: "Kepemimpinan itu di tangan Quraisy" tiga kali, selama mereka melaksanakan tiga perkara yaitu: Apabila menghakimi, berlaku adil, apabila diminta belas kasih, mereka akan memberikan belah kasih, dan apabila mereka berjanji, menepati. Barang siapa di antara mereka tidak melakuakan tiga hal tersebut, maka laknat Allah, malaikat, dan seluruh manusia atas mereka. ${ }^{11}$

Sementara itu penelusuran terhadap shahih Bukhari terdapat empat riwayat. Dua hadis terdapat dalam kitab Manaqib, yaitu pada Manaqib al Quraisydan dua lagi termuat dalam kitab al Ahkam, yaitu pada bab al Umara min Quraisy. Adapun di antara hadisnya adalah:

Artinya:

Telah bercerita kepada kami, Abū alYamān, telah memberitakan kepada kami Syu'aeb dari al-Zuhrī, dia berkata: Muhammad bin Zubair bin Muţ'im menceritakan bahwa Mu'āwiyah mendapat berita bahwa 'Abd Allāh ibn 'Amr menceritakan bahwa akan ada seorang raja dari suku Qaţān, maka Muāwiyah marah dan berdiri seraya memuji Allah dengan pujian yang menjadi hak-Nya, dan berkata: "Ammā ba'du, sesungguhnya aku menerima

\footnotetext{
${ }^{10}$ Ahmad bin Muhammad, Musnad ...,h. 93.

${ }^{11}$ Ahmad bin Muhammad, Musnad..., Juz IV,
}

h. 421 . 
berita bahwa beberapa orang laki-laki memberitakan pembicaraan- pembicaraan yang tidak terdapat dalam kitab Allah dan tidak diambil dari sunnah Rasulullah saw., mereka itu adalah orang yang bodoh diantaramu. Maka takutlah kamu terhadap angan-angan yang akan menyesatkan pemiliknya; Karen sesungguhnya aku mendengar Rasulullāh saw. besabda: "Sesungguhnya kepemimpinan itu ada pada Quraisy, siapa saja yang memusuhi mereka, pastilah Allah akan membuatnya jatuh tersungkur, selamamereka masih menegakkan hukum-hukum agama ini. ${ }^{12}$

Hadis berikutnya yang senada dengan pembahasan ini adalah :

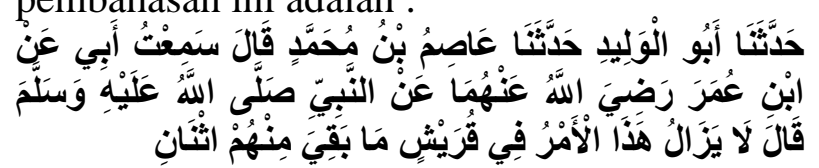

Artinya:

Menceritakan kepada kami Abū al-Walīd, menceritakan kepada kami 'Āshīm bin Muhammad ia berkata, aku mendengar ayahku dari Ibn 'Umar ra ia berkata: "Kepemimpinan ini tetap ada di tangan Quraisy selama masih ada dua orang diantara mereka. ${ }^{13}$

Hadis selanjutnya adalah:

Artinya :

Menceritakan kepada kami, Abū alYamān, memberitakan kepada kami Syu'aeb dari al-Zuhrī, dia berkata: Muhammad bin Zubair bin Muţ'im menceritakan bahwa Mu'āwiyah mendapat berita bahwa 'Abd Allāh bin 'Amr menceritakan bahwa akan ada seorang raja dari suku Qaţān, maka Mu'āwiyah marah lalu berdiri seraya memuji Allah dengan pujian yang menjadi hak-Nya, kemudaian ia mengatakan: "Ammā ba'du, Sesungguhnya aku menerima kabar bahwa beberapa orang laki-laki memberitakan pembicaraan-pembicaraan yang tidak terdapat dalam kitab Allah dan tidak diambil dari sunnah Rasulullāh saw., mereka itu adalah orang yang bodoh diantaramu. Maka takutlah

${ }^{12} \mathrm{Abu}$ Abd Allah Muhammad bin Isma'il alBukhārī, Shahih al-BukhārīJuz IV (t.tp.: Dar MuţAbī SyAbī, t.t..), h. 217-218 dan Juz IX, h. 217-218.

13 Al-Bukhārī, Shahih.....Juz IV, h. 217-218 dan Juz IX, h. 217-218. kamu terhadap angan-angan yang akan menyesatkan pemiliknya; Karena sesungguhnya aku mendengar Rasulullāh saw. besabda: "Sesungguhnya kepemimpinan itu ada pada Quraisy, siapasaja yang memusuhi mereka, pastilah Allah akan membuatnya jatuh tersungkur, selama mereka masih menegakkan hukumhukum agama ini. $^{14}$

\section{Nilai Kehujjahan Hadis}

Keterangan tentang semua redaksi teks hadis kepemimpinan Quraisy beserta jalur periwayatan sanadnya dibutuhkan untuk menghindari pemaknaan secara parsial tentang hadis ini. Jalur periwayatan hadis-hadis kepemimpinan Quraisy secara keseluruhan sebagai berikut:

a.

eks hadis dengan penggunaan lafadz al Aimmah min Quraisy termaktub dalam kitab Musnad Ahmad bin Hanbal yang berisi sejumlah delapan riwayat

b. Teks hadis dengan menggunakan lafadz lain yaitu la yazalu termuat dalam tiga jalur periwayat hadis yaitu, Ahmad bin Hanbal, Muslim dan Bukhari

c. Total periwayat dalam hadis ada 34 orang dan di antaranya ada 3 orang yang merupakan mukharrij

d. Dalam periwayatan hadis ini lafadz tahammul yang dipakai adalah dengan memakai kata Qala, sami'tu, sana, haddasana, akhbarana, 'an dan inna

e. Dalam penelusuran terdapat periwayat yang tidak disebut namanya secara jelas, yaitu pada jalur sanad al Bukhari, sebutannya adalah Abu al Yaman. Dalam kitab Tahdzib al Tahdzibnya al Asqalani, beliau menyatakan bahwa sebutan tersebut adalah Al Hakam bin Nafi' al

${ }^{14}$ Al-Bukhārī, Shahih.....Juz IX, h. 77-78. 
Bahrani. ${ }^{15}$ Kemudian ada lafadz ' an abi dari riwayat Abd Allah ibn 'Umar yang terdapat pada tiga jalur sanad, al Bukhari, Muslim dan Ibn Hanbal. Setelah dicek kembali ternyata penyebutan itu tertuju pad Muhammad bin Zayd 'Abd Allah bin 'umar. ${ }^{16}$

Hadis tentang kepemimpinan bani Quraisy yang telah ditelusuri dan diambil dari riwayat Bukhari dan Ahmad bin Hanbal, baik sanad dan matannya adalah shahih (shahih al matn wa shahih al isnad). Oleh karena hadishadis tersebut adalah shahih, maka dapat diterima (maqbul). 'Ajjaj al Khatib menyatakan bahwa salah satu syarat suatu hadis dapat digolongkan dalam hadis maqbul adalah jika telah diketahui bahwa perawiperawi yang ada dalam hadis tersebut tidak mengandung cacat/kelemahan atau saqim. ${ }^{17}$ Hadis ini dapat diamalkan karena di dalamnya ada syarat sebagai hadis yang menimbulkan keyakinan dan memiliki kegunaan dalam keilmuan.

\section{Sekilas Tentang Urgensi, Prinsip dan Syarat Kepemimpinan}

Di antara para pemikir muslim menyatakan bahwa keberadaan pemimpin adalah sebuah keharusan (wajib). ${ }^{18}$ Kewajiban tersebut berdasar pada kespakatan para sahabat dan tabi'in. Namun yang menjadi perbedaan pendapat adalah terletak pada asal pengambilan tentang kewajiban tersebut. Ada

\footnotetext{
${ }^{15}$ Ahmad bin 'Alī bin Hajar al-Aśqalan̄̄, Tahż̄̄b $a t-T a h z ̇ \bar{l} b$, Juz II, (Beirut: Dar Shadir, t.ţ.), h. 441.

${ }^{16}$ Jamal al-Din Abī al-Hajjāj Yusuf al-Mizzī, Tahż̄̄b alKamāl fí Asmā' al-Rijal, Juz XXV, (t.tp: Muassasat alRisalah, 1985), hlm. 226-227.

${ }^{17}$ Muhammad 'Ajjaj al Khatib, Ushul al Hadis : 'Ulumuh wa Musthalahuh (Beirut: Dar al Fikr, 1989), h. 303 dan Mahmud at Thahhan, Taisir Musthalah al Hadis (Indonesia: Al Haramain, 1985.), h. 55-56

${ }^{18}$ Pernyataan tentang hal ini bisa dilihat dalam, Al Mawardi, Al Ahkam Al Sultaniyyah wa al Wilayat al Diniyyah (Beirut: Dar Al Kutub al Ilmiyah, 2006), h. 5. Lihat juga Ibn Khaldun, Muqaddimah (Mesir: Maktabah Mustafa Muhammad, tt), h. 190 dan juga Ahmad Salabi, Al Siyasah al Iqtishad fi tafkir al Islami(Kairo: Maktabah al Nahdah al Mishriyah, 1984), h. 29
}

yang menyatakan berdasar pada ketetapan syari'at, tetapi ada juga yang berargumentasi kepada ketetapan rasional.

Dalam menanggapi perdebatan tersebut, khususnya kelompok yang berpendapat bahwa kepemimpinan itu harus diadakan berdasar pada logika dan kebutuhan manusia kepada organisasi serta ketidak mungkinan hidup sendiri-sendiri, juga sebagai salah satu konsekwensi logis dari adanya organisasi adalah munculnya perbedaan pendapat dan perselisihan maka diperlukan pemimpin yang akan mengendalikannya, Ibn Khaldun tidak sepakat dengan pendapat ini. Beliau menyatakan adanya perselisihan dan perbedaan pendapat tidaklah dengan sendirinya dihilangkan dengan adanya kepemimpinan. Kedua hal ini bisa dieliminir dengan banyak cara, seperti adanya usaha perbaikan yang dilakukan masyarakat dengan menghindari perselisihan dan prilaku zhalim, serta bisa diatasi dengan peraturan syari'at. Ibn Khaldun berpendapat bahwa keharusan mendirikan kepemimpinan berdasar pada syari'at melalui konsensus ${ }^{19}$

Terlepas dari perdebatan tersebut di atas, kalau diamati kewajiban adanya pemimpin tersebut merujuk kepada beberapa dalil atau argumentasi berikut ini : pertama, firman Allah dalam surat al Nisa ayat 59 :

Artinya : Hai orang-orang yang beriman, taatilah Allah dan taatilah Rasul (Nya), dan ulil amri di antara kamu. kemudian jika kamu berlainan Pendapat tentang sesuatu, Maka kembalikanlah ia kepada Allah (Al Quran) dan Rasul (sunnahnya), jika kamu benar-benar beriman kepada Allah dan hari kemudian. yang demikian itu lebih utama (bagimu) dan lebih baik akibatnya. (Q.S. Al-Nisa' ayat 59). Ayat ini menjelaskan tentang ketaatan kepada ulil amri. Kemudian ayat yang lain terdapat pada surat Al Nisa ayat 83 :

$$
\text { Artinya : "Dan apabila datang }
$$
kepada mereka suatu berita tentang keamanan ataupun ketakutan, mereka lalu

${ }^{19}$ Ibn Khaldun, Muqaddimah..., h. 191-192 
menyiarkannya. dan kalau mereka menyerahkannya kepada Rasul dan ulil Amri di antara mereka, tentulah orang-orang yang ingin mengetahui kebenarannya (akan dapat) mengetahuinya dari mereka (Rasul dan ulil Amri) kalau tidaklah karena karunia dan rahmat Allah kepada kamu, tentulah kamu mengikut syaitan, kecuali sebahagian kecil saja (di antaramu). "(Q.S.Al Nisa' ayat 83). Ayat ini menjelaskan tentan peran Ulil Amri dalam menentukan situasi negara dalam kondisi aman atau genting.

Adapun argumentasi yang kedua adalah hadis yang menyatakan apabila ada tiga orang mengadakan perjalanan, maka hendaklah mengangkat salah seorang di antara mereka menjadi pemimpin. ${ }^{20} \mathrm{Hadis}$ tersebut adalah:

Artinya :

Telah menceritakan kepada kami Abu Daud dari Ali bin Bahr dari Hatim bin Isma'il dari Muhammad bi 'Ajlan dari Nafi' dari Abi Salamah dari Abu Sa'id Al Khudri bahwasanya Rasulullah Saw bersabda : "Apabila ada tiga orang keluar untuk melakukan musafir maka hendaklah salah seorang di antara mereka untuk menjadi pemimpin".

Hadis kedua adalah tentang manusia yang paling dicintai dan dekat dengan Allah pada hari kiamat adalah imam atau pemimpin yang adil. ${ }^{21}$ Hadis tersebut adalah:

Artinya :

Telah menceritakan kepada kami 'Ali bin al Mundzir al Kaufi dari Muhammad bin Fudhail dari Fudhail bin Marzuq dari 'Athiyyah dari Abi Sa'id berkata telah bersabda Rasulullah Saw : "Sesungguhnya manusia yang paling dicintai Allah hari kiamat dan mereka denganNya adalah kelompok Imam yang 'adil dan yang paling dibenci adalah kelompok pemimpin yang curang (berbuat kezhaliman dan dosa).

Argumentasi yang ketiga adalah pendapat ulama salaf al shalih, antara lain:

${ }^{20}$ Hadis ini riwayat Imam Al Baihaqi, Sunan Al Baihaqi al Kubra, Juz 5, h. 257. Maktabah Syamilah

21 Hadis ini riwayat at Tirmidzi, Sunan at Tirmidzi, juz 5, h.164. Maktabah Syamilah pernyataan Abu Bakar saat wafatnya rasul, "sesungguhnya Muhammad telah melalui jalannya, dan agama ini harus tetap ada yang menjaganya". Kemudian pernyataan Umar bin Khattab, "Tidak ada Islam tanpa komunitas dan tidak ada komunitas tanpa adanya kepemimpinan, dan tidak ada artinya kepemimpinan tanpa adanya ketaatan. ${ }^{22}$

Setelah mengemukakan tentang pentingnya mengangkat pemimpin, maka di sini akan diuraikan tentang prinsip-prinsip dalam pelaksanaan kepemimpinan. Ada tiga prinsip yang harus ditegakkan dalam menjalankan roda kepemimpinan menurut Ibn Taimiyah. Ketiga prinsip tersebut adalah pertama, amanat, kedua, keadilan, dan ketiga adalah musyawarah.

Prinsip pertama dan kedua berlandaskan kepada pada pernyataan Allah dalam surat al Nisa' ayat 58 yaitu :

Artinya: "Sesungguhnya Allah menyuruh kamu menyampaikan amanat kepada yang berhak menerimanya, dan (menyuruh kamu) apabila menetapkan hukum di antara manusia supaya kamu menetapkan dengan adil. Sesungguhnya Allah memberi pengajaran yang sebaik-baiknya kepadamu. Sesungguhnya Allah adalah Maha mendengar lagi Maha melihat."

Ibn Taimiyah memberikan penjelasan tentang lafadz amanat dalam konteks ayat tersebut di atas. Ada dua pemahaman dari lafadz tersebut menurutnya yaitu, pertama, amanat adalah adanya tanggung jawab pemimpin dalam hal pengelolaan kepentingan-kepentingan rakyat. Pengelolaan tersebut akan terealisasi dengan sempurna apabila aparat yang berada di sekitar pemimpin memiliki kapabilitas dan kecakapan. Pemahaman yang kedua adalah amanat tersebut berkaitan dengan otoritas melaksanakan pemerintahan yang dimiliki pemimpin. Dalam pelaksanaan otoritas tersebut pemimpin haruslah memilih wakil dan aparatnya yang kompeten dan punya kemampuan, karena kalau tidak maka hal ini

h. 29
${ }^{22}$ Ahmad Salabi, Al Siyasah al Iqtishad fi ...., 
merupakan penodaan terhadap amanat tersebut. ${ }^{23}$ Realisasi prinsip amanat ini salah satunya adalah "the right man on the right place" atau menurut Ibn Taimiyah penempatan orang yang aslahsesuai dengan jabatan dan kapabilitasnya. $^{24}$ Apabila dalam prosedur pemilihan wakil dan aparatnya didasari oleh faktor kedekatan atau pertemanan, nepotisme, etnisitas, adanya kolusi atau yang sejenisnya yang mengarah kepada kemungkaran, maka pemimipin yang seperti ini dikategorikan sebagai pemimpin yang telah melakukan penzhaliman dengan mengkhianati amanah Allah, Rasul sekaligus rakyat yang dipimpinnya. Bahkan lebih dari hal itu menjadi faktor hancurnya kehidupan berbangsa dan bernegara. ${ }^{25}$ Rasul Saw pernah bersabda dalam sebuah hadis.

Poin penting dalam hadis tersebut menyatakan bahwa apabila suatu urusan diserahkan kepada selain ahlinya, maka tunggulah saat kehancurannya.

Adapun prinsip yang kedua yaitu keadilan menurut Ibn Taimiyah ada dua jenisnya yaitu keadilan syar'iyah dan 'aqliyah. Keadilan syar'iyah dapat diperoleh melalui penerapan semua hukum syari'at, sementara keadilan 'aqliyah dapat diwujudkan dengan menerapkan kaedah akal dan indera yang meliputi kemanfaatan bagi hidup dan kehidupan manusia. ${ }^{26}$

Prinsip yang ketiga setelah amanah dan adil di atas adalah musyawarah. Allah Swt berfirman dalam surat Ali 'Imran ayat 159 yaitu :

Artinya : "Maka disebabkan rahmat dari Allah-lah kamu Berlaku lemah lembut

${ }^{23}$ Munawir Sjadzali, Islam dan Tata Negara ( Jakarta: UI Press, 1993), h. 86

${ }^{24}$ Ahmad bin 'Abd al-Halīm bin 'Abd as-Salām Ibn Taimiyyah, Al-Siyasah al-Syar'iyyah fi Ishlah Ra'i wa Ra'iyyah.( Beirut: Dar al-Kutub al-Ilmiyyah, 1988), h. 14

${ }^{25}$ Ahmad bin 'Abd al-Halīm bin 'Abd as-Salām Ibn Taimiyyah, Al-Siyasah al-Syar'iyyah fi Ishlah Ra'i..., h. 17-18

${ }^{26}$ Ahmad bin 'Abd al-Halīm bin 'Abd as-Salām Ibn Taimiyyah, Al-Siyasah al-Syar'iyyah fi Ishlah Ra'i..., h. 121. terhadap mereka. Sekiranya kamu bersikap keras lagi berhati kasar, tentulah mereka menjauhkan diri dari sekelilingmu. karena itu ma'afkanlah mereka, mohonkanlah ampun bagi mereka, dan bermusyawaratlah dengan mereka dalam urusan itu. kemudian apabila kamu telah membulatkan tekad, Maka bertawakkallah kepada Allah. Sesungguhnya Allah menyukai orang-orang yang bertawakkal kepada-Nya."

Dan juga di ayat yang lain yang berkenaan dengan musyawarah ini terdapat pada surat Al-Syura ayat 38 yaitu:

Artinya : "Dan (bagi) orang-orang yang menerima (mematuhi) seruan Tuhannya dan mendirikan shalat, sedang urusan mereka (diputuskan) dengan musyawarat antara mereka; dan mereka menafkahkan sebagian dari rezki yang Kami berikan kepada mereka."

Dalam menganalisa perintah musyawarah dari surat Ali imran di atas, Ibn Taimiyah menyatakan bahwa perintah musyawarah ditujukan kepada nabi Muhammad sebagai pemimpin masyarakat. Dan kenapa nabi diperintah untuk melakukan musyawarah menurutnya ada tiga alasan yaitu : pertama untuk menarik simpati dan melembutkan hati para sahabat, kedua memberi teladan agar menjadi panutan untuk umat selanjutnya dan yang ketiga sebagai suatu mekanisme untuk memunculkan ide-ide bernas dan terbaik sebagai solusi atas berbagai persoalan yang tidak tercantum dalam wahyu". ${ }^{27}$

Setelah menelusuri prinsip kepemimpinan maka selanjutnya akan dibahas tentang syarat-syarat untuk menjadi pemimpin. Para pemikir politik Islam klasik telah menguraikan kriteria pemimpin dengan begitu ketatnya demi terjaganya prinsip maslahah 'ammah. Imam al Mawardi telah menetapkan beberapa syarat untuk menjadi pemimpin yaitu : Memiliki sikap adil. Mempunyai ilmu yang memadai untuk melakukan ijtihad. Sehat indera (pendengaran, penglihatan, dan lisan). Utuh anggota tubuh.
${ }^{27}$ Munawir Sjadzali, Islam dan Tata....., h. 
Memiliki keluasan wawasan untuk bisa mengatur kehidupan rakyat dan mengelola kepentingan umum. Punya keberanian untuk melindungi rakyat dan memberantas musuh. Keturunan Quraisy. ${ }^{28}$

Sementara itu, Ibn Khaldun meringkas menjadi beberapa kriteria utama yaitu: 1. Memiliki pengetahuan ('ilm), 2. Adil, 3. Memiliki kemampuan untuk melaksanakan tugasnya, 4. Anggota badannya tidak cacat dan panca inderanya normal, 5. Berasal dari kaum Quraisy. ${ }^{29}$

\section{Kajian tentang suku Quraisy sebagai syarat kepemimpinan}

Syarat untuk menjadi pemimpin harus berasal dari suku Quraisy menjadi sebuah perdebatan di kalangan ulama. Ibn Khaldun menjelaskan bahwa syarat ini muncul dari konsensus para sahabat pada waktu hari Saqifah. Di saat itu dari golongan Anshar bermaksud membaiat Sa'ad bin Ubadah. Namun dari pihak Muhajirin menolak sembari mengutip sabda rasul, " kepemimpinan itu dari orang Quraisy”. Argumentasi ini pun diterima oleh pihak anshar dan mereka membatalakan pembaiatan Sa'ad.

Ibn khaldun lebih lanjut menyatakan bahwa kekuasaan bangsa Quraisy melemah pada tataran abad kemudian. Solidaritas mereka lenyap sebagai akibat hidup mewah dan berlebihan. Mereka pun semakin lemah dan bangsa non Arab banyak menguasai mereka. Kenyataan ini menimbulkan perbedaan pendapat tentang persyaratan mengenai suku Quraisy tersebut. Menurut Ibn Khaldun jika syarat ini tetap dipertahankan, maka akan bertentangan dengan ijma' dan syarat-syarat kepemimpinan lainnya. Jika orang Quraisy yang telah lemah menjadi pemimpin, maka bisa diprediksi bahwa dia akan lemah dalam memimpin kekuasaannya. Hal ini akan bertentangan dengan syarat ketiga yaitu kifayah (memiliki kemampuan yang memadai). Bila syarat ini di hapus maka akan berpengaruh kepada syarat-syarat yang

${ }^{28} \mathrm{Al}$ Mawardi, Al Ahkam Al Sultaniyyah...., h. 6-7bisa juga dilihat, Munawir Sjadzali, Islam dan ...., h. 63-64,

${ }^{29}$ Ibn Khaldun, Muqaddimah..., h. 193 lainnya. ${ }^{30}$

Namun meskipun demikian, Ibn Khaldun mencari hikmah dengan adanya pensyaratan terhadap suku Quraisy tersebut. Dalam konteks ini, beliau berpendapat bahwa yang dikehendaki oleh syarat tersebut sesungguhnya adalah adanya kemampuan atau capable memimpin yang timbul dari solidaritas sosial. Oleh karena itu, salah satu syarat terpenting bagi seseorang yang bertugas menangani persoalan masyarakat adalah orang yang termasuk dari kelompok yang memiliki solidaritas yang kuat, dan berada di atas solidaritas kelompok-kelompok lainnnya. Golongan superior ini berganti ataupun berbeda-beda dalam setiap waktu dan tempat.

Sementara itu Ibn Taimiyyah juga memberikan pemahaman terhadap hadis-hadis yang mengindikasikan persyaratan terhadap suku Quraisy. Meskipun beliau kurang dikenal sebagai tokoh hadis, namun keilmuannya di bidang hadis ini tidak bisa "disepelekan". Pemahaman beliau terhadap hadis ini bisa dilacak dalam dua karya monumentalnya yaitu, Minhāj as-Sunnah fì naqdi kalām asySȳ̇'ah wa al-Qadariyyah dan as-Siyāsah asySyar'iyyah fì Islāhi ar-Rā'̄̄ wa ar-Ra'iyyah.

Ibn Hajar al Asqalani juga memberikan komentar tentang berbagai pemahaman terhadap teks hadis tersebut. Beliau menyatakan bahwa tidak ada seorang ulama pun kecuali dari kelompok Mu'tazilah dan Khawarij yang membolehkan jabatan kepala negara diduduki oleh orang yang tidak berasal dari suku Quraisy. ${ }^{31}$

Di samping para pemikir di atas, tokoh politik Islam modern juga mengomentari tentang pemahaman terhadap hadis tersebut di atas, yaitu Taqiyuddin Nabhani. Beliau mengelompokkan persyaratan menjadi pemimpin dalam dua kategori: pertama, syarat In'iqad (yaitu berupa syarat mutlak yang harus dimiliki oleh seseorang yang akan dicalonkan menjadi pemimpin), yang kedua disebut dengan syarat afdhaliyyat (keutamaan)

\footnotetext{
${ }^{30}$ Ibn Khaldun, Muqaddimah..., h. 195

${ }^{31}$ Ali Ahmad bin Ali Ibn Hajar al-Asqalaniy, Fath al-Bari Syarh Shahih al-Bukhariy, (t.tp : Dar alFikr wa Maktabah, t.t), h. 114-118.
} 
sebagai syarat tambahan, seperti, pemberani, mujtahid dan berasal dari keturunan Quraisy. ${ }^{32}$ Dalam hal ini terdapat perbedaan pendapat antara beberapa tokoh pemikir politik muslim klasik dengan Nabhani. Taqiyuddin Nabhani menganggap syarat kepemimpinan yang berasal dari suku Quraisy sebagai syarat elementer yang tidak menentukan keabsahan kepemimpinan, sementara tokoh pemikir muslim klasik menjadikannya sebagai syarat utama.

Sementara itu, Syuhudi Ismail menyatakan bahwa diperlukan pemahaman secara kontekstual terhadap hadis tersebut. Beliau menyatakan bahwa hak kepemimpinan bukan pada etnis Quraisynya, tetapi pada hakekatnya bertumpu kepada kemampuan dan kewibawaannya. Di masa Nabi, kelompok masyarakat yang memenuhi syarat untuk dijadikan sebagai pemimpin dan dipatuhi perkataannya adalah dari kalangan Quraisy. Tidak tertutup kemungkinan di suatu masa ada orang yang bukan dari kalangan etnis Quraisy tetapi memiliki kewibawaan dan kapabilitas dalam hal kepemimpinan bahkan bisa jadi melebihi etnis Quraisy, maka dia bisa diangkat dan ditetapkan sebgai pemimpin atau kepala negara. Dan menurut beliau, pemahaman kontekstual seperti ini dipelopori pertama kali oleh Ibn Khaldun(808H,1506M).

Berkenaan dengan pemahaman terhadap hadis secara utuh, Said Agil Husin Al Munawwar juga menawarkan alternatif dengan menggunakan berbagai pendekatan dalam memahami hadis ini. Beliau menyatakan bahwa kemungkinan bisa diterapkan pendekatan historis, sosiologis, antropologis, atau bahkan pendekatan psikologis sebagai pisau analisis dalam memahami hadis. Kerangka berpikirnya didasarkan pada suatu anggapan bahwa Nabi Saw tidak mungkin menyampaikan suatu wacana atau pernyataan dalam kondisi yang historis atau hampa sejarah dan budaya. Suatu ide, gagasan, pemikiran bahkan termasuk sabda Nabi Saw selalu

\footnotetext{
${ }^{32}$ Taqiyyudin An-Nabhani,

Sistem Pemerintahan Islam. terj. Moh Maghfur Wachid. (Bangil: Al-Izzah, 1997), h. 66-73.
}

berdasarkan kenyataan sejarah serta terkait dengan masalah historis-kultural pada masa itu. $^{33}$.

\section{SIMPULAN}

Dari uraian yang dijelaskan dalam pembahasan diatas, maka penulis akan menarik kesimpulan. Adapun yang menjadi kesimpulan penulis dalam topik bahwa seseorang berhak menjadi seorang peminpin apabila ia mempunyai keahlian dalam bidangnya.

Adapun pendekatan yang dilakukan dengan menggunakan pendekatan sosiologis terhadap Hadis di atas dapat diketahui bahwa keturunan Quraisy tidak dimaksudkan sebagai syarat mutlak bagi jabatan kepala negara yang ditetapkan oleh Nabi, sehingga mengikat seluruh umat secara abadi. Hadis tersebut hanya menunjukkan bahwa kepemimpinan dari keturunan Qurasiy hanya sebagai syarat keutamaan, karena memang terkenal dengan solidaritasnya.

Hadis tersebut hanya bersifat lokaltemporal. Karena bertolak belakang dengan prinsip al-Qur'an yang menyatakan bahwa yang paling utama dihadapan Allah adalah orang yang paling bertakwa, bukan dari kalangan, golongan atau keturunan manapun (tidak ada pengkhusususan untuk kaum Quraisy).

\section{DAFTAR PUSTAKA}

A.J. Wensinck, Al-Mu'jam al-Mufahras li Alfāz al-Hadīs an-Nabawī, Juz I, (Leiden: E-J.Brill, 1942).

Abu Abd Allah Muhammad bin Isma'il alBukhārī, Shahih al-Bukhārī, Juz IV (t.tp.: Dar MuţAbī SyAbī, t.ţ.)

Abul A'la al-Maududi, Hukum dan Konstitusi Sistem Politik Islam, Terjemahan

33 Said Agil Husin Al Munawwar dan Abdul Mustaqim, Asbabul Wurud: Studi Kritis Hadis Nabi Pendekatan Sosio-Historis-Kontekstual(Yogyakarta: Pustaka Pelajar, 2001), h.6. 
Deliar Noer dari The Islamic Law and Constitution, (Bandung: Mizan, 1993). Ahmad bin 'Abd al-Halīm bin 'Abd as-Salām Ibn Taimiyyah, Al-Siyasah alSyar'iyyah fi Ishlah Ra'i wa Ra'iyyah.( Beirut: Dar al-Kutub alIlmiyyah, 1988).

Ahmad bin 'Abd al-Halīm bin 'Abd as-Salām Ibn Taimiyyah, Minhāj as-Sunnah $f i$ naqdi kalām asy-Syi'ah wa alQadariyyah, Juz III, Cet. IV, (alQāhirah: Dār al-Hadīs).

Ahmad bin Muhammad bin Hanbal, Musnad Imam Ahmad bin Hanbal, Juz II (Beirut: al-Maktabah al-Islamī, 1398).

Ahmad Salabi, Al Siyasah al Iqtishad fi tafkir al Islami(Kairo: Maktabah al Nahdah al Mishriyah, 1984).

Al Mawardi, Al Ahkam Al Sultaniyyah wa al Wilayat al Diniyyah (Beirut: Dar Al Kutub al Ilmiyah, 2006).

Ali Ahmad bin Ali Ibn Hajar al-Asqalaniy, Fath al-Bari Syarh Shahih al-Bukhariy, (t.tp : Dar al-Fikr wa Maktabah, t.t).

Ayatullah Murtadha Muthahhari, Islam dan Tantangan Zaman terjemahan Ahmad Sobandi dari kitab Inna al-Din'inda Allah al-Islam, (Jakarta: Sadra International Institute, 2011).

Ibn Khaldun, Muqaddimah (Mesir: Maktabah Mustafa Muhammad, tt).

Imam al-Mawardi, al-Ahkâm al-Sulthâniyyah wa al-Wilâyat al-Dîniyyah, (Beirut: Dâr al-fikr, tt).

M. Syuhudi Ismail, Kaedah Kesahihan Sanad Hadis: Telaah Kritis dan Tinjauan dengan Pendekatan Ilmu Sejarah, Cet. II (Jakarta: P.T. Bulan Bintang, 1995).
M. Syuhudi Ismail, Metodologi Penelitian Hadis Nabi, Cet. II (Jakarta: P.T. Bulan Bintang, 2007).

Mahmud at Thahhan, Taisir Musthalah al Hadis (Indonesia: Al Haramain, 1985).

Maktabah Syamilah , Al Tirmidzi, Sunan at Tirmidzi, juz 5.

Maktabah Syamilah, Imam Al Baihaqi, Sunan Al Baihaqi al Kubra, Juz 5.

Muhammad 'Ajjaj al Khatib, Ushul al Hadis : 'Ulumuh wa Musthalahuh (Beirut: Dar al Fikr, 1989).

Munawir Sjadzali, Islam dan Tata Negara ( Jakarta: UI Press, 1993).

Musfar Azmullah al Damini, Maqayis Naqd Mutun al Sunnah (Riyadh: Jami' al Huquq mahfudzah li al Muallaf, 1984).

Said Agil Husin Al Munawwar dan Abdul Mustaqim, Asbabul Wurud: Studi Kritis Hadis Nabi Pendekatan SosioHistoris-Kontekstual(Yogyakarta: Pustaka Pelajar, 2001).

Shalahuddin al Adlabi, Manhaj al Naqd al Matan (Beirut: Dar Jadidah, 1983).

Syaikh Muhammad Al Ghazali, Hadis Nabi saw : Antara Pemahaman Tekstual dan Kontekstual, alih bahasa oleh Muhammad al Baqir (Bandung: Penerbit Mizan, 1998).

Taqiyyudin Al-Nabhani, Sistem Pemerintahan Islam. terj. Moh Maghfur Wachid. (Bangil: Al-Izzah, 1997). 